\title{
Portuguese Passive House case study: a comparison between monthly and seasonal energy performance methods
}

\author{
N. Simões ${ }^{1,2}$, D. Teles ${ }^{1} \&$ C. Serra ${ }^{1}$ \\ ${ }^{I}$ TeCons - Institute for Research and Technological Development for \\ Construction, Energy, Environment and Sustainability, Portugal \\ ${ }^{2}$ ADAI - LAETA, Department of Civil Engineering, \\ University of Coimbra, Portugal
}

\begin{abstract}
Buildings are responsible for $40 \%$ of final energy consumption in the European Union. Thus, it is crucial to calculate their energy performance during both the design and use phases. During the design phase, estimating energy performance allows the definition of appropriate solutions to incorporate in the building envelope, while during the use phase it is relevant for the identification of adequate improvement measures. The Energy Performance of Buildings Directive recommends that member states shall use a common methodology for calculating the energy performance based on European or international standards. One of the most relevant standards is the ISO 13790 which provides two general types of methods, one of which is the quasi-steady-state method, where energy balance is typically calculated over one month or a whole season and dynamic effects are taken into account by using an empirical gain and/or loss utilization factor.

This paper presents a brief comparison between two quasi-steady-state methods that are being applied in Portugal: a seasonal approach which is mandatory under the current legislation and a voluntary monthly approach proposed by the Passivhaus Institute.

This comparison was performed using an existing residential house certified by the Passivhaus Institute as the case study. Furthermore, to better evaluate the thermal and energy level of this particular case study, a sensitivity analysis was performed using different climate data for Portugal (Lisbon, Oporto and Ílhavo) and other regions in Europe. The impact of climate variation in Europe was evaluated in terms of Passivhaus criteria verification using the monthly approach.
\end{abstract}


It was demonstrated that cities with a similar climate to that of the Portuguese case, such as Rome, need little to no changes in order to achieve the Passivhaus standard. However, in other cities like Berlin, Dublin or Helsinki the building will need some improvements in order to achieve the full requirements.

Keywords: energy performance of buildings, monthly and seasonal method, passive house.

\section{Introduction}

The building sector (both residential and non-residential) is responsible for $40 \%$ of the energy consumption and $36 \%$ of the $\mathrm{CO}_{2}$ emissions in Europe [1].

In 2002, the European Union (EU) published the Directive 2002/91/EC, known as the first Energy Performance of Buildings Directive (EPBD) [2]. Its implementation by the EU member states has promoted the energy labelling of new and existing buildings and stimulated the definition of new levels of envelope insulation and better levels of performance by the technical systems installed in buildings. The success of this directive encouraged its recast, and, in 2010, the Directive 2010/31/EU was published with new and more ambitious goals [3]. As a result, European member states were required to adapt their regulations in order to achieve Nearly Zero-Energy Building (NZEB) concept levels by the end of 2020 for all new residential buildings, and by 2018 for public buildings [3-6]. Even though this concept is yet to be fully defined, a NZEB is understood to be a building which has very high energy performance and whose low amount of energy consumption come mostly from renewable sources.

According to collected data, in Portugal, in 2012 the building sector was responsible for $29 \%$ of total primary energy consumption [7]. Residential and nonresidential buildings consume almost $60 \%$ of the all of the electrical energy used in the country. Since its origin, the main goals stated in the national legislation for the energy performance in buildings have been the reduction of energy consumption and the mitigation of hygrothermal pathologies. The publication of the EPBD directives was transposed in Portugal resulting in a number of decreelaws. Residential dwellings were first covered by a regulation known as the RCCTE [8], however, after the EPBD recast it has been replaced by the DecreeLaw n⿳118/2013 [9], published on 20 August of 2013, known as REH.

Globally, the tightening of the energy performance requirements has stimulated the procurement of new building standards, one of which is the passive house concept which, following the example given by Germany in the early 1990s, emerged as an option for designing highly efficient buildings. Broadly, this concept consists in energy efficient construction focused on promoting a heavily insulated envelope and placing tight restrictions on the occurrence of thermal bridges and air tightness. The purpose of the Passivhaus Standard is for comfortable indoor conditions to be ensured using solely a mechanical ventilation system for heating [10, 11].

In the EPBD it is stated that the energy performance regulatory codes developed within each European country must follow a general common framework and must be based on the calculation guidelines described in the 
European standard EN ISO 13790:2008 [12]. This standard proposes two general types of calculation methodologies: quasi-steady-state and dynamic. In a quasisteady-state method energy balance is calculated typically over one month or during a whole season, while in a dynamic method energy balance is estimated using short times steps (typically of one hour). Whereas the Portuguese energy certification of residential buildings is based on the seasonal approach, the Passivhaus trademark follows a monthly calculation method. Even though they are both steady-state approaches, they follow different guidelines and the Passivhaus Standard does not carry any national official recognition. Since this passive house certification does not exclude buildings from the verification of national requirements, designers and owners may be faced with different energy performance levels for the same building.

In this work, a comprehensive study is performed on a real certified passive house located in the central region of Portugal. A detailed comparison between the seasonal method of the REH and the monthly method of the Passivhaus Institute is described. Firstly, the main differences regarding the data required, the calculation methodologies employed and their effect on the results are discussed. Secondly, the monthly method is applied to the same case study for different locations in Europe, with the purpose of understanding the different improvements that need to be performed to achieve the Passivhaus Standard criteria in varying regions.

\section{Case study}

The building, illustrated in Figure 1, is a semi-detached house (dwelling B) built in Ílhavo, which is located on the west boarder coast of Portugal (latitude of $40^{\circ}$ 36 ', $7 \mathrm{~km}$ away from the Atlantic Ocean). The local climate classification can be placed between the typical oceanic and Mediterranean climates [13].

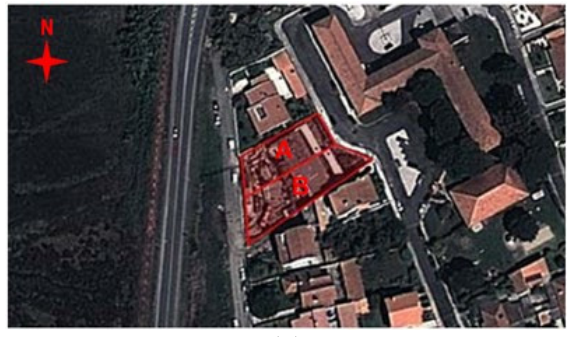

(a)

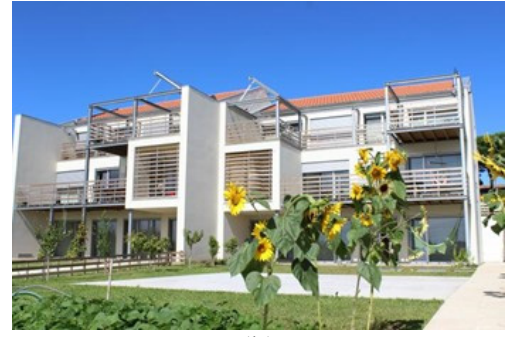

(b)

Figure 1: Case study passive house: (a) map location of the passive house studied (dwelling B) and a neighbouring passive house (dwelling A); (b) photograph of the passive house studied (dwelling B, on the right) and a neighbouring passive house (dwelling $\mathrm{A}$, on the left).

This single-family home is a certified passive house with 3 floors, where the ground floor has two bedrooms, two bathrooms and a living area. The first floor 
includes the kitchen, another living room, a bathroom, the garage and the laundry room. The last floor has two bedrooms, a bathroom and an open space study area. The total area is $223.7 \mathrm{~m}^{2}$. The windows have double glazing $(6 / 16 / 4 \mathrm{~mm})$ and the facade with the higher glazed area faces west. The house has double brick walls with an insulation layer of $100 \mathrm{~mm}$. The building solutions lead to high thermal inertia.

The house is equipped with a mechanical ventilation system with heat recovery that offers $77 \%$ of efficiency and a total supply air flow rate of $190 \mathrm{~m}^{3} / \mathrm{h}$. The air permeability rate of the envelope at $50 \mathrm{~Pa}\left(\mathrm{n}_{50}\right)$ is $0.45 \mathrm{~h}^{-1}$, obtained using the fan pressurization standard method described in EN 13829:2000 [14].

To produce domestic hot water (DHW), the house uses a south facing solar collector of $4.6 \mathrm{~m}^{2}$, connected to a storage tank with around 300 litres of capacity. To suppress additional DHW needs there is also a compact heat pump unit with a Coefficient of Performance (COP) greater than 2.0.

\section{Quasi-steady-state methods comparison}

The quasi-steady-state methods that are being compared are based on different assumptions: one is seasonal and follows the guidelines published in Decree-Law $\mathrm{n}^{\circ} 118 / 2013$ (REH) [9], while the other is a monthly method. REH calculations were performed using the tool developed by ITeCons which is used extensively by the Portuguese experts responsible for performing the energy certification of buildings. The application of the latter is attained using the Passive House Planning Package (PHPP) developed by the Passivhaus Institute.

The interior temperature reference for the heating season is $18^{\circ} \mathrm{C}$ under the Portuguese seasonal method (REH), while PHPP considers $20^{\circ} \mathrm{C}$. In the cooling season, both methods consider a reference set-point temperature of $25^{\circ} \mathrm{C}$. Additionally, between the two methods, DHW estimations consider different average daily consumption values: 40 litres per person are considered in the seasonal method against only 25 litres per person in the monthly method. According to the PHPP, the DHW demand can be guaranteed with a solar collector area of about $1 \mathrm{~m}^{2} /$ person, while in the REH it is mandatory that the solar energy generated for DHW heating is equivalent to the one obtained from an area of $0.65 \mathrm{~m}^{2} /$ person of a standard collector with defined features.

Table 1 presents the results obtained by following the guidelines of each method. To enable a comparison between the methods, listed in the table are the transmission heat losses, ventilation heat losses, internal gains, solar gains, heat and cooling energy demands and primary energy needs.

The heating energy demand for the seasonal REH method is around $35 \%$ of the result obtained using the PHPP method. In the monthly method, the energy needs during the cooling season are completely suppressed, while in the seasonal method $18.5 \mathrm{kWh} /\left(\mathrm{m}^{2} \cdot \mathrm{a}\right)$ are required. Considering that the input data related with the building characteristics were similar, it is important to understand if the different results are caused mainly by the methodological differences or by the boundary conditions - climate data and reference interior temperature. Table 2 compares the climate data for heating and cooling available in each standard (REH and PHPP). 
It can be said that the climate data values present considerable differences. We must not forget that in order to correctly follow each method it is mandatory to use the data available for each. When performing both certifications methods to the same building this may bring on doubts for the designer and lead to owners' loss of reliability regarding the certification processes.

Table 1: $\quad$ Energy balance results using seasonal and monthly approaches for a passive house located in Ílhavo (Portugal).

\begin{tabular}{|c|c|c|c|}
\hline & & $\begin{array}{c}\text { Seasonal method } \\
(\mathrm{REH})\end{array}$ & $\begin{array}{l}\text { Monthly method } \\
\text { (PHPP) }\end{array}$ \\
\hline \multirow{4}{*}{$\begin{array}{l}\text { Heating } \\
\text { Season }\end{array}$} & $\begin{array}{l}\text { Transmission heat losses } \\
(\mathrm{kWh} / \mathrm{a})\end{array}$ & 9845.0 & 10107.0 \\
\hline & Ventilation heat losses $(\mathrm{kWh} / \mathrm{a})$ & 825.7 & 874.0 \\
\hline & Solar gains $(\mathrm{kWh} / \mathrm{a})$ & 13889.9 & 9174.0 \\
\hline & Internal gains $(\mathrm{kWh} / \mathrm{a})$ & 3997.0 & 2041.0 \\
\hline \multirow{4}{*}{$\begin{array}{l}\text { Cooling } \\
\text { Season }\end{array}$} & $\begin{array}{l}\text { Transmission heat losses } \\
(\mathrm{kWh} / \mathrm{a})\end{array}$ & 4025.5 & 6980.0 \\
\hline & Ventilation heat losses (kWh/a) & 1446.7 & 11232.0 \\
\hline & Solar gains $(\mathrm{kWh} / \mathrm{a})$ & 6745.7 & 5204.0 \\
\hline & Internal gains $(\mathrm{kWh} / \mathrm{a})$ & 2620.0 & 1725.0 \\
\hline \multicolumn{2}{|c|}{ Heating energy demand $\left[\mathrm{kWh} /\left(\mathrm{m}^{2} \mathrm{a}\right)\right]$} & 2.4 & 7.0 \\
\hline \multicolumn{2}{|c|}{ Cooling energy demand $\left[\mathrm{kWh} /\left(\mathrm{m}^{2} \mathrm{a}\right)\right]$} & 18.5 & 0.0 \\
\hline \multicolumn{2}{|c|}{ Primary energy needs $\left[\mathrm{kWh} /\left(\mathrm{m}^{2} \mathrm{a}\right)\right]$} & 23.2 & $24.9^{(1)}$ \\
\hline
\end{tabular}

(1) To compare with the seasonal method, the value of $24.9 \mathrm{kWh} /\left(\mathrm{m}^{2} \mathrm{a}\right)$ corresponds to heating, cooling and DHW needs. Under the PHPP, a primary energy result of $67 \mathrm{kWh} /\left(\mathrm{m}^{2} \mathrm{a}\right)$ was obtained, including the additional consideration of auxiliary $\left(5.9 \mathrm{kWh} /\left(\mathrm{m}^{2} \mathrm{a}\right)\right)$ and household electricity $\left(36.2 \mathrm{kWh} /\left(\mathrm{m}^{2} \mathrm{a}\right)\right)$ needs.

Further energy calculations were performed using normalized climate data by adjusting the seasonal climate data to the monthly one (also presented in Table 2).

Since the transmission is largely dependent on the heating degree-days, differences occur due to the season length, reference temperature and climate database considerations. However, considering similar heating periods (181 days) and set-point interior temperatures $\left(20.0^{\circ} \mathrm{C}\right)$ in both methods, the total transmission losses during winter were $25 \%$ higher using the seasonal method. Although not presented in this article, it was found that the major difference in terms of the transmission heat losses occurred in the opaque envelope (mainly due to the thermal bridges assessment). This difference can be justified by the fact that, during the simulation of the seasonal method, the ISO 14683:2007 [15] was used and linear thermal transmission coefficients were taken from the online thermal bridges catalogue developed by ITeCons [16].

In the summer, using the same length for the cooling period in both methods, only a difference of $9 \%$ was obtained.

In terms of heat balance due to the ventilation mechanism, there is a considerable difference between the two simulations, particularly in the cooling season simulation. While in the monthly PHPP simulation night ventilation is 
Table 2: Comparison of the climate data for Ílhavo and normalization using the monthly input.

\begin{tabular}{|c|c|c|c|}
\hline & \multicolumn{2}{|c|}{ Seasonal method (REH) } & \multirow{2}{*}{$\begin{array}{c}\text { Monthly } \\
\text { method } \\
\text { (PHPP) }\end{array}$} \\
\cline { 2 - 3 } & Original data & $\begin{array}{c}\text { Normalization with } \\
\text { the monthly method }\end{array}$ & 181 days \\
\hline Length heating period & 186 days $^{(1)}$ & 181 days & 153 days \\
\hline Length cooling period & 122 days $^{(2)}$ & 153 days & $41.0 \mathrm{kKh} / \mathrm{a}$ \\
\hline $\begin{array}{c}\text { Degree-days in heating } \\
\text { season }\end{array}$ & $30.8 \mathrm{kKh} / \mathrm{a}^{(3)}$ & $38.7 \mathrm{kKh} / \mathrm{a}^{(6)}$ & $26.0 \mathrm{kKh} / \mathrm{a}$ \\
\hline $\begin{array}{c}\text { Degree-days in cooling } \\
\text { season }\end{array}$ & $11.7 \mathrm{kKh} / \mathrm{a}^{(4)}$ & $14.7 \mathrm{kKh} / \mathrm{a}^{(7)}$ & \\
\hline $\begin{array}{c}\text { Solar radiation in } \\
\text { heating season (south) }\end{array}$ & $868.0 \mathrm{kWh} / \mathrm{m}^{2} \mathrm{a}^{(5)}$ & $844.7 \mathrm{kWh} / \mathrm{m}^{2} \mathrm{a}^{(8)}$ & $572.0 \mathrm{kWh} / \mathrm{m}^{2} \mathrm{a}$ \\
\hline $\begin{array}{c}\text { Solar radiation in } \\
\text { cooling season (south) }\end{array}$ & $420.0 \mathrm{kWh} / \mathrm{m}^{2} \mathrm{a}$ & $526.72 \mathrm{kWh} / \mathrm{m}^{2} \mathrm{a}^{(9)}$ & $529.0 \mathrm{kWh} / \mathrm{m}^{2} \mathrm{a}$ \\
\hline $\begin{array}{c}\text { Interior set-point temp. } \\
\text { (heating season) }\end{array}$ & $18.0^{\circ} \mathrm{C}$ & $20.0^{\circ} \mathrm{C}$ & $20.0^{\circ} \mathrm{C}$ \\
\hline $\begin{array}{c}\text { Interior set-point temp. } \\
\text { (cooling season) }\end{array}$ & $25.0^{\circ} \mathrm{C}$ & $25.0^{\circ} \mathrm{C}$ & $25.0^{\circ} \mathrm{C}$ \\
\hline $\begin{array}{c}\text { Exterior temperature } \\
\text { (cooling season) }\end{array}$ & \multicolumn{2}{|c|}{$9.7^{\circ} \mathrm{C}$} & $10.5^{\circ} \mathrm{C}$ \\
\hline $\begin{array}{c}\text { Exterior temperature } \\
\text { (heating season) }\end{array}$ & $20.7^{\circ} \mathrm{C}$ & $19.6^{\circ} \mathrm{C}$ \\
\hline
\end{tabular}

(1) The heating season has a duration of 6.2 months;

(2) The cooling period lasts 2928 hours;

(3) According to the seasonal method the degree-days in winter are $1284^{\circ} \mathrm{C} \cdot$ days. To convert this value to $\mathrm{kKh} / \mathrm{a}$, it was multiplied by 24 hours/day and divided by 1000 ;

(4) The length of the cooling season in the seasonal method was multiplied by $4^{\circ} \mathrm{C}$ (difference between the interior and exterior) and divided by 1000 ;

(5) The solar radiation in winter (140 kWh/month) was multiplied by the heating length (in months) of the seasonal method.

(6) To obtain the degree-days in winter for the same interior temperature, the value obtained in (3) was added $2^{\circ} \mathrm{C}$ multiplied by the length of the heating season and divided by 1000 . To adjust the heating period, the result obtained before was multiplied by 181 days and divided by 186 days;

(7) To obtain the degree-days in summer, (2) is multiplied by 153 days and divided by 122 days (cooling period adjustment);

(8) To obtain the solar radiation, (5) is multiplied by 181 days and divided by 186 days (heating period adjustment);

(9) To adjust the cooling period, the solar radiation is calculated multiplying $420 \mathrm{kWh} / \mathrm{m}^{2}$ a by 153 days and divided by 122 days.

considered, in the seasonal REH simulation this option is not possible to consider. The loss through night ventilation represents almost $50 \%$ of all of the ventilation heat loss during the summer. The estimation of the natural ventilation in the monthly method gives a higher air rate $\left(1.09 \mathrm{~h}^{-1}\right)$ when compared to $0.6 \mathrm{~h}^{-1}$ provided by the seasonal method. Assuming the same air change rate and similar climate data, as expected, the heat balance becomes quite similar since the heat transfer coefficient is also very similar.

For both heating and cooling seasons, the calculated solar gains are higher using the seasonal method. According to Table 2, the solar radiation in winter is 
almost $36 \%$ higher in the seasonal method compared to the monthly method. Assuming the radiation of the monthly method in the calculation of the solar gains of the seasonal method, the result is $9146 \mathrm{kWh} / \mathrm{a}$, which is close to the one obtained in the monthly method. In summer, the south facing solar radiation has similar values when the duration of the season is the same. However, there is a difference in radiation of $9 \%$ for west and $29 \%$ for east. The result is an increase of heat gains around $500 \mathrm{kWh} / \mathrm{a}$. Additionally, there are small differences between the two methods such as the angle selective factor ( 0.90 for monthly and 0.85 for seasonal) and the consideration of a dirt factor in the monthly method.

The estimation of internal heat gains, which include heat from appliances, lighting and living bodies, is considerably different between both methods. The main reason for this discrepancy is due to the fact that, according to $\mathrm{REH}$, the specific internal heat load for residential buildings has a value of $4 \mathrm{~W} / \mathrm{m}^{2}$, which is also the value adopted by the EN ISO 13790:2008 [12] and, by default, the PHPP tool considers a constant specific internal load of $2.1 \mathrm{~W} / \mathrm{m}^{2}[11]$.

The primary energy in the monthly method presented a higher value, mostly because it takes into account some domestic electronic devices (like cooking, electrical home appliances, etc.), which does not happen in the seasonal method. The consideration of these heat resources together with a utilization frequency average makes the simulation more similar to the real use of the building. Nevertheless, when the auxiliary and household electricity are not considered in the primary energy given by the monthly method, it was shown that both models present similar values.

Concluding, it was observed that the climate data reveals to have the greatest influence in results. Internal gains also lead to an important difference, as well as the possibility considering night cooling during the cooling season, which is only allowed in the monthly method.

\section{The passive house in different European climate regions}

Energy consumption depends on the climate conditions of each location. The Passive House concept was initially defined for central European countries. As the requirements are kept the same in disparate regions, the construction solutions designed to fulfil those requirements may be considerably different $[11,17]$. In this section it was investigated if the dwelling studied would achieve the Passivhaus Standard requirements in different regions around Europe. When they were not reached, required improvement measures were evaluated. Using the PHPP 7, five locations in Europe were simulated for the same case study presented before: Postdam (Berlin), Dublin, Helsinki, Madrid and Rome.

Table 3 presents the climate characteristics of each city, including three cities in Portugal, while Table 4 shows the energy demand results.

When the building is placed in Portugal (Ílhavo, Lisbon and Oporto), we conclude that the Passivhaus requirements are verified. However, there is a slight difference between the energy demand in the north and the south of Portugal. For example, in Lisbon, where the annual heating/cooling energy demand is around $1 \mathrm{kWh} /\left(\mathrm{m}^{2} \cdot \mathrm{a}\right)$ the heating energy demand can be mostly suppressed if we take 
additional passive measurements like optimizing the orientation and adjusting the window-to-wall ratio along with their optic and thermal characteristics [18].

Table 3: Climate characteristics of the five European cities (PHPP).

\begin{tabular}{|l|l|c|c|c|c|}
\hline & $\begin{array}{c}\text { Type of } \\
\text { climate }\end{array}$ & $\begin{array}{c}\text { Radiation } \\
\text { average } \\
(\mathrm{south}) \\
\mathrm{kWh} /\left(\mathrm{m}^{2} \cdot \mathrm{a}\right)\end{array}$ & $\begin{array}{c}\text { Daylight } \\
\text { length } \\
\text { hours }\end{array}$ & $\begin{array}{c}\text { Average } \\
\text { exterior } \\
\text { temperature } \\
\text { in winter } \\
\left({ }^{\circ} \mathrm{C}\right)\end{array}$ & $\begin{array}{c}\text { Average } \\
\text { exterior } \\
\text { temperature } \\
\text { in summer } \\
\left({ }^{\circ} \mathrm{C}\right)\end{array}$ \\
\hline Berlin & $\begin{array}{l}\text { Cold } \\
\text { temperate }\end{array}$ & 338 & $8-17$ & 0.4 & 18.4 \\
\hline Dublin & $\begin{array}{l}\text { Cold } \\
\text { temperate }\end{array}$ & 391 & $7.5-17$ & 6.7 & 15.2 \\
\hline Ílhavo & Warm & 528 & $10-15$ & 9.5 & 19.6 \\
\hline Lisbon & Warm & 344 & $10-15$ & 12.1 & 22.4 \\
\hline Madrid & $\begin{array}{l}\text { Warm } \\
\text { temperate }\end{array}$ & 468 & $9-15$ & 9.6 & 29 \\
\hline Oporto & Warm & 380 & $10-15$ & 10.2 & 19.6 \\
\hline Rome & $\begin{array}{l}\text { Warm } \\
\text { temperate }\end{array}$ & 574 & $9-15$ & 8.9 & 26.4 \\
\hline Helsinki & Cold & 339 & $6-19$ & -6.6 & 16.9 \\
\hline
\end{tabular}

Table 4: Energy demand when the same building is placed in Berlin, Dublin, Helsinki, Ílhavo, Lisbon, Madrid, Oporto and Rome, and limit requirements of the Passivhaus Standard.

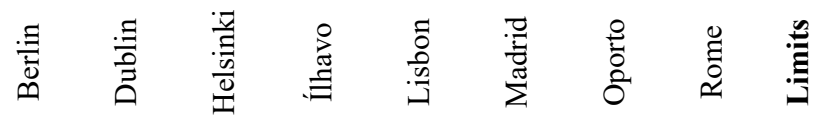

\begin{tabular}{lccccccccc}
\hline $\begin{array}{l}\text { Annual heating } \\
\text { demand } \\
\mathrm{kWh} /\left(\mathrm{m}^{2} \mathrm{a}\right)\end{array}$ & 64 & 41 & 104 & 7 & 1 & 5 & 4 & 8 & $\mathbf{1 5}$ \\
$\begin{array}{l}\text { Heating load } \\
\mathrm{W} / \mathrm{m}^{2}\end{array}$ & 30 & 21 & 41 & 10 & 9 & 11 & 9 & 14 & $\mathbf{1 0}$ \\
$\begin{array}{l}\text { Space cooling } \\
\text { demand } \\
\mathrm{kWh} /\left(\mathrm{m}^{2} \mathrm{a}\right)\end{array}$ & 0 & 0 & 0 & 0 & 1 & 24 & 0 & 14 & $\mathbf{1 5}$ \\
$\begin{array}{l}\text { Cooling load } \\
\mathrm{W} / \mathrm{m}^{2}\end{array}$ & 4 & 0 & 0 & 4 & 9 & 29 & 5 & 12 & $\mathbf{1 0}$ \\
$\begin{array}{l}\text { Primary } \\
\begin{array}{l}\text { Energy } \\
\mathrm{kWh} /\left(\mathrm{m}^{2} \mathrm{a}\right)\end{array}\end{array}$ & 219 & 152 & 335 & 67 & 53 & 62 & 59 & 70 & $\mathbf{1 2 0}$ \\
$\begin{array}{l}\text { Passivhaus } \\
\text { verification }\end{array}$ & No & No & No & Yes & Yes & No & Yes & Yes & \\
\hline
\end{tabular}


Nevertheless, in the other cities around Europe, except for Rome, the Passivhaus criteria were not achieved. Although the cooling load in Rome is higher than the limit, the cooling demand does not exceed the limit, which what is accepted by the standard as regular. Rome has a Mediterranean climate similar to Portugal, but with higher temperatures during the cooling season and consequently higher cooling loads.

In the case of Madrid, heating indicators are within the limits, while both cooling energy loads and needs exceed the limits. The risk of overheating in summer is high ( $29 \%$ of probability of overheating). The overheating is defined as the number of times that the interior temperature exceeds a given set-point of $25^{\circ} \mathrm{C}$, as defined by the PHPP. The PHPP recommends that additional measures for cooling should be taken when the overheating rate exceeds $10 \%$ [19]. The application of proper solar shading devices like overhangs, awnings and blinds is one of the strategies that should be promoted. Another measure is the increase of ventilation during the cooling season, with preference for to the opening of windows. The installation of an active cooling system may be considered as a last resource. Previous studies [20,21] showed that in warm south-eastern climates the use of an active cooling system may be really necessary.

In Berlin and Dublin, the cooling demand is within the limits, while the annual heating demand, the heating load and also the primary energy needs fail to meet the requirements. To overcome this problem, energy efficiency measures such as an improved heat recovery system, higher levels of insulation and windows with lower U-value, should be considered during the design phase. This high value of the heating demand can be explained by the fact that in these regions the solar radiation presents low values and the winter temperatures are lower than in southern countries.

In the case of Helsinki, the Passivhaus requirements do not follow the same rules. Different criteria were defined by the VTT Technical Research Center of Finland during the European Project "Promotion of European Passive House". The criteria imposed in Finland are present in Table 5. Nevertheless, even with the increase of the upper limits, the building does not respect them. Similar strategies as those mentioned for the case of Berlin and Dublin need to be followed.

Table 5: $\quad$ Energy demand limits for Helsinki, according to the VTT.

\begin{tabular}{|l|l|}
\hline Annual heating demand $\left[\mathrm{kWh} /\left(\mathrm{m}^{2} \cdot \mathrm{a}\right)\right]$ & $\begin{array}{l}20-30 \\
(\text { depending on the location) }\end{array}$ \\
\hline Annual cooling demand $\left[\mathrm{kWh} /\left(\mathrm{m}^{2} \cdot \mathrm{a}\right)\right]$ & $\begin{array}{l}20-30 \\
(\text { depending on the location) }\end{array}$ \\
\hline Leakage air rate $\mathrm{n}_{50}\left[\mathrm{~h}^{-1}\right]$ & 0.6 \\
\hline Primary energy $\left[\mathrm{kWh} / \mathrm{m}^{2} \cdot \mathrm{a}\right]$ & $130-140$ \\
\hline
\end{tabular}

According to the Passivhaus Institute, each climate requires different solutions for the building envelope and systems [22]. An exercise where a set of modifications were introduced in the monthly simulation was performed. For example, the façade with higher glazing area was faced south, in the case of cold regions, and to north, for warmer regions. However, the change in the orientation 
of the building was not enough to verify the requirements. Additional changes need to be implemented in each city as listed in Table 6. A qualitative scale is used in order to better understand which measures were applied in each case.

Table 6: Summary of the improvement measures according to each city: The symbol "+" means an improvement of the parameter. The symbol "-" means a reduction of the parameter and "NA" means not applicable in this case.

\begin{tabular}{|l|c|c|c|c|c|}
\hline & $\begin{array}{c}\text { Heat } \\
\text { recovery } \\
\text { system }\end{array}$ & $\begin{array}{c}\text { Insulation } \\
\text { layer }\end{array}$ & $\begin{array}{c}\text { Orientation } \\
\text { (majority of } \\
\text { glazing area) }\end{array}$ & Windows & $\begin{array}{c}\text { Night } \\
\text { ventilation }\end{array}$ \\
\hline Berlin & ++ & ++ & South & +++ & NA \\
\hline Dublin & + & ++ & South & ++ & NA \\
\hline Helsinki & ++ & +++ & South & +++ & NA \\
\hline Madrid & NA & + & North & + & + \\
\hline
\end{tabular}

With these measures the house initially planned for Portugal may achieve the full Passivhaus requirements in other regions. However, a cost-optimal study should follow, in order to understand if the passive house solutions should vary depending on the climate of each country, not only for new construction but also for retrofitting [22, 23].

\section{Conclusion}

This paper compares two quasi-steady-state methods that are being applied in Portugal for evaluating of the energy performance of buildings: one is seasonal and mandatory under current legislation, while the other, proposed by the Passivhaus Institute, is voluntary and follows a monthly approach. The comparison was performed using an existing residential house already certified as a passive house by the Passivhaus Institute. It was concluded that the difference in climate data is the most significant reason for the discrepancies observed between the methods. Firstly, the two methods use different heating set-point temperatures. The seasonal method presents a lower value of $18^{\circ} \mathrm{C}$, while the monthly method considers $20^{\circ} \mathrm{C}$, and greater solar radiation. As a consequence, the heating needs using the seasonal method are lower than in the monthly simulation. On the other hand, the high values of the radiation in summer, lead to some difficulties in verifying the cooling needs. In the monthly simulation the cooling needs were neglected because it was possible to assume higher rates of ventilation, in particular during the night-time. Moreover, if the building was initially designed according to the best practice of the Passivhaus Standard the heating demand could also be largely reduced.

When the case study was placed in other cities around Europe, the results demonstrated that in cities with a similar climate as Portugal, such as Rome, the passive house requirements are achieved without changes. However, in hotter (Madrid) or colder (Berlin, Dublin or Helsinki) climates, the dwelling does not 
fulfil all of the criteria. Without any change in terms of architecture it was proved to be possible to verify the requirements by improving the envelope and selecting technical systems which are more efficient.

\section{Acknowledgements}

This work has also been supported by the POCI-01-0247-FEDER-003408 (Slimframe PV \& Cork Ski) Project funded by Portugal 2020 through the Operational Programme for Competitiveness Factors (COMPETE 2020) and by the doctoral FCT grant SFRH/BD/91686/2012. The authors are also grateful to Homegrid for their support.

\section{References}

[1] EC@(2016).https://ec.europa.eu/energy/en/topics/energy-efficiency/ buildings. European Commission (Official website, accessed January 2016).

[2] Directive 2002/91/EC: Energy Performance of Buildings Directive (EPBD). Directive of the European Parliament and of the Council of 16 December 2002.

[3] Directive 2010/31/EC: Energy Performance of Buildings Directive (EPBD). Directive of the European Parliament and of the Council of 19 May 2010 (recast).

[4] Oliveira Panão, M. J. N., Camelo, S. M. L., \& Gonçalves, H. J. P. Solar Load Ratio and ISO 13790 methodologies: Indirect gains from sunspaces. Energy and Buildings, 51, pp. 212-222, 2012.

[5] Michalak, P. The simple hourly method of EN ISO 13790 standard in Matlab/Simulink: A comparative study for the climatic conditions of Poland. Energy, 75, pp. 568-578, 2014.

[6] Salvalai, G., Masera, G., \& Sesana, M. M. Italian local codes for energy efficiency of buildings: Theoretical definition and experimental application to a residential case study. Renewable and Sustainable Energy Reviews, 42, pp. 1245-1259, 2015.

[7] DGEG@(2016).http://www.dgeg.pt/. Direção Geral de Energia e Geologia (Official webpage), Lisbon.

[8] Decreto-Lei n. ${ }^{\circ}$ 80/2006 de 4 de abril, N. ${ }^{\circ} 67$ - 4 de abril de 2006 (Diário da República - I Série A 2006).

[9] Decreto-Lei $n^{\circ} 118 / 2013$ de 20 de agosto, Sistema de Certificação Energética dos Edifícios, No 159 - 20 de agosto de 2013 (Diário da República $-1^{\text {a }}$ Série 2013).

[10] M. L. Persson, A. Roos, M. Wall, Influence of Window size on the energy balance of low energy houses, Energy and Buildings, 38, pp. 181-188, 2006.

[11] Feist Wolfgang, Puger R, Kaufmann B, Schnieders J, Kah O. Passive house planning package 2007. Darmstadt: Passive House Institute, June 2007. 
[12] ISO 13790:2008 (E), Energy Performance of Buildings - Calculation of Energy Use for Space Heating and Cooling, 2008.

[13] Marcelino, J., \& Gavião, J. G. The Passive House in Portugal: encouraging its spread in South West Europe, International Passive House Conference in Frankfurt, 2013.

[14] EN 13829:2000, Thermal performance of buildings - Determination of air permeability of buildings - Fan pressurization method (ISO 9972:1996, modified), 2000.

[15] ISO 14683:2007, Thermal bridges in building construction -Linear thermal transmittance - Simplified methods and default values, 2007.

[16] ITeCons@(2016) http://www.itecons.uc.pt/catalogopt1/. ITeCons (official website, accessed January 2016)

[17] Feist Wolfgang, User manual for Passive House Planning Package 2007, Passive House Institute, Darmstadt, Germany, 2010.

[18] Ferreira, J., Pinheiro, M. In search of better energy performance in the Portuguese buildings - The case of the Portuguese regulation. Energy Policy, 39(12), 7666-7683, 2011.

[19] Bahrami, S. Energy efficient buildings in warm climates of the Middle East: Iiiee, Master's Thesis, Lund University, Department of Energy Sciences, Lund, Sweden, 2008.

[20] Badescu, V., Laaser, N., Crutescu, R. Warm season cooling requirements for passive buildings in Southeastern Europe (Romania). Energy, 35(8), 3284-3300, 2010.

[21] Badescu, V., Laaser, N., Crutescu, R., Crutescu, M., Dobrovicescu, A., \& Tsatsaronis, G. Modeling, validation and time-dependent simulation of the first large passive building in Romania. Renewable Energy, 36(1), 142-157, 2011.

[22] Utveckling, H., Wan, M. Building Retrofitting According to the Concept of Passive Houses-A Case Study of Täljstensvägen 7A-C, Master's Thesis, Department of Energy Sciences, Lund, 2013.

[23] Tadeu S., Alexandre R., Tadeu A., Antunes C.H., Simões N., Pereira da Silva P., 2016 - A comparison between cost optimality and return on investment for energy retrofit in buildings - A real options perspective. Sustainable Cities and Society, 21, pp. 12-25. 